\title{
Embriogenesis, Perkembangan Larva dan Viabilitas Reproduksi Ikan Pelangi Iriatherina Werneri Meinken, 1974 Pada Kondisi Laboratorium
}

\author{
Embryogenesis, Larval Development and Reproduction Viability of Threadfin Rainbowfish \\ Iriatherina Werneri Meinken, 1974 Under Laboratory Conditions
}

\author{
Muh. Herjayanto ${ }^{1}$, Odang Carman ${ }^{2}$, Dinar Tri Soelistyowati ${ }^{2}$ \\ ${ }^{1}$ Mahasiswa Magister, Program Studi Ilmu Akuakultur, Sekolah Pascasarjana, Institut Pertanian Bogor \\ ${ }^{2}$ Departemen Budidaya Perairan, FPIK-IPB \\ Jl. Agatis, Kampus IPB, Dramaga, Bogor 16680 \\ fherja@yahoo.com
}

\begin{abstract}
Abstrak
Ikan pelangi Iriatherina werneri diperdagangkan sebagai ikan hias, karena memiliki warna dan bentuk sirip yang indah terutama untuk individu jantan. Perkembangan budidaya ikan pelangi terkendala oleh kurangnya informasi biologi terkait perkembangan embrio (embriogenesis), perkembangan larva, viabilitas reproduksi dan sejarah kehidupannya. Tujuan dari penelitian untuk mengkaji embriogenesis, perkembangan larva dan viabilitas reproduksi pada ikan pelangi I. werneri sebagai informasi dasar untuk menunjang kegiatan budidaya dan konservasi. Pengamatan embriogenesis menggunakan 100 butir embrio yang dimasukkan pada empat buah wadah inkubasi berukuran $(19,5 \times 13,5 \times 8,5) \mathrm{cm}^{3}$. Pengamatan viabilitas reproduksi dan pertumbuhan menggunakan 200 butir embrio yang dimasukkan pada lima buah wadah berukuran $(19,5 \times 19,5 \times 19,5) \mathrm{cm}^{3}$. Hasil penelitian menunjukkan bahwa embrio ikan pelangi berkembang mulai dari fase pembelahan sel, morula, blastula, gastrula, organogenesis dan menetas menjadi larva pada saat $124 \mathrm{jam} 5$ menit setelah pembuahan. Telur mulai menetas pada hari keempat $(15,11 \%)$ dan berakhir pada hari keenam $(23,35 \%)$ dengan puncak penetasan terjadi pada hari kelima $(61,54 \%)$ setelah pembuahan. Ikan telah menjadi juvenil pada umur 35 hari setelah menetas dengan panjang total $>12 \mathrm{~mm}$. Viabilitas reproduksi $I$. werneri pada penelitian ini yaitu tingkat penetasan sebesar $62,04 \%$; tingkat kelangsungan hidup sampai umur 50 hari setelah menetas sebesar $62,72 \%$ dan ikan jantan secara alami sebanyak $20 \%$.
\end{abstract}

Kata kunci : Embriogenesis, Iriatherina werneri, perkembangan larva, viabilitas reproduksi

\begin{abstract}
The threadfin rainbowfish Iiratherina werneri have marketed as ornamental fish, because of their color and fins is beautiful especially for male. Development of threadfin rainbowfish breeding constrained because very little known about their biology information such as embryo development (embryogenesis), larval development, reproduction viability and life history. The purpose of the study to assess embryogenesis, larval development and reproduction viability in fish rainbow $I$. werneri as baseline information to support aquaculture and conservation. The study of embryogenesis used 100 eggs placed in four containers $(19.5 \times 13.5 \times 8.5) \mathrm{cm}^{3}$, while larval development and reproduction viability used 200 eggs placed in five containers $(19.5 \times 19.5 \times 19.5) \mathrm{cm}^{3}$. Result showed that the development stages embryogenesis I. werneri was started from cleavage phase, morula, blastula, gastrula, organogenesis and hatched become a larvae at 124 hour 5 minutes after fertilization. The eggs began hatching at four days after fertilization $(15.11 \%)$, ended at six days after fertilization (23.35\%), with hatching peak at five days after fertilization $(61.54 \%)$. The fish become juvenile at 35 days after hatching with total length above $12 \mathrm{~mm}$. Reproduction viability $I$. weneri about hatching rate was $52.90 \%$, survival rate 50 days after hatching was $76.25 \%$ and total male was $20 \%$ in this research.
\end{abstract}

Keywords : Embryogenesis, Iriatherina werneri, larval development, reproduction viability 
Muh. Herjayanto : Embriogenesis, Perkembangan Larva dan Viabilitas Reproduksi Ikan Pelangi Iriatherina Werneri Meinken, 1974 Pada Kondisi Laboratorium

\section{Pendahuluan}

Habitat alami ikan pelangi Iriatherina werneri adalah perairan rawa dan sungai yang mengalir lambat serta terdapat tanaman air. Ikan ikan terdistribusi di pulau Papua bagian tengah sampai selatan dan Australia bagian utara (Tappin 2011, Unmack et al., 2013). Ikan ini diperdagangkan sebagai ikan hias, karena memiliki warna dan bentuk sirip yang indah terutama untuk individu jantan. Tercatat harga ikan jantan di pasar lokal Rp. 400-5.000 ekor ${ }^{-1}$ atau 30-50 kali lipat dibandingkan harga ikan betina, sedangkan di pasar internasional dapat mencapai 12-36 kali lipat dibandingkan harga jantan di pasar lokal (Herjayanto, 2016).

Umumnya pengembangan budidaya ikan pelangi terkendala pada sedikitnya informasiinformasi dasar mengenai biologi dan sejarah kehidupannya di alam (Humphrey et al., 2003; Tappin, 2011). Pada spesies I. werneri, penelitian yang telah dilakukan yaitu deskripsi dan klasifikasinya (Allen, 1980; Unmack et al., 2013), adaptasi terhadap beberapa jenis pakan (Said $d k k ., 2006$ ) dan performa berenang pada ikan jantan (Trappet et al., 2013). Terkait reproduksinya telah diteliti tentang performa pemijahan melalui perbedaan lama waktu pengistirahatan induk (Rahmadani, 2015), tingkah laku memijah, potensi reproduksi ikan betina dan optimasi teknik pemijahan pada wadah budidaya (Herjayanto, 2016). Kemudian penelitian untuk peningkatan populasi jantan tentang maskulinisasi melalui penggunaan ekstrak tanaman purwoceng Pimpinella alpina (Nurkhasanah, 2015), feminisasi dengan hormon estradiol-17 $\beta$ (Firmansyah, 2016) dan nisbah kelamin pada perbedaan suhu pemeliharaan (Rakhmawati, 2016).

Selain itu, informasi dasar yang juga penting diketahui adalah perkembangan embrio (embriogenesis), perkembangan larva (Humphrey et al., 2003; Chumaidi $d k k ., 2009$ ) dan viabilitas reproduksi (Said, 2008). Informasi tentang perkembangan awal dan sejarah kehidupan ikan memberikan parameter penting untuk produksi benih (Çelik et al., 2011). Oleh karena itu, tujuan dari penelitian untuk mengkaji embriogenesis, perkembangan larva dan viabilitas reproduksi pada ikan pelangi $I$. werneri sebagai informasi dasar untuk menunjang kegiatan budidaya dan konservasi.

\section{Metode Penelitian}

\section{Adaptasi induk}

Induk ikan pelangi berasal dari pembudidaya ikan hias di desa Tegalwaru, Kecamatan Ciampea, Bogor, Jawa Barat. Ukuran ikan betina dan jantan yang digunakan berkisar 2,5$3 \mathrm{~cm}$ dengan umur berkisar antara 50-60 hari (Gambar 1). Ikan tersebut terlebih dahulu diadaptasikan selama tujuh hari dalam wadah terpisah antara jantan dan betina serta diberi pakan komersial merek dagang Feng $\mathrm{Li}$ berbentuk tepung yang mengandung protein 36,05\%; lemak 5,96\%; kadar air 7,93\% dan abu $12,68 \%$. Pakan diberikan secara at satiation dengan frekuensi tiga kali sehari (pukul 06.00, 12.00 dan 17.00). Penyifonan feses dan sisa pakan dilakukan setiap hari. Setelah diadaptasikan, induk dipilih yang siap mijah untuk digunakan pada pengamatan penelitian.

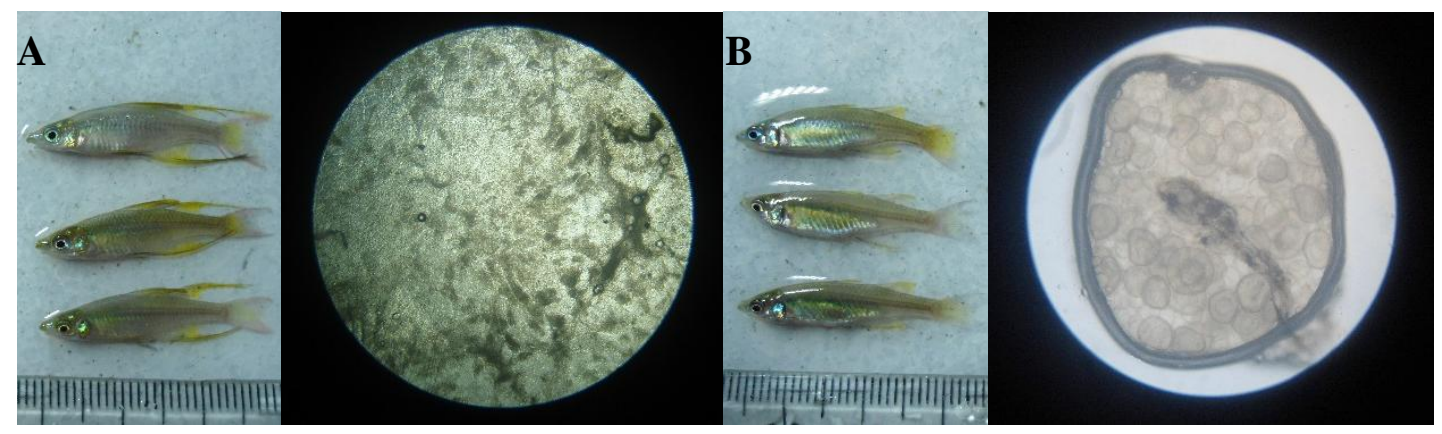

Gambar 1. Ciri morfologi dan gonad ikan pelangi Iriatherina werneri. A. jantan, B. betina Figure 1. Characteristic morphology and gonad rainbow fish Iriatherina werneri
A. Male,
B. Female 


\section{Pemijahan}

Wadah pemijahan menggunakan empat buah akuarium berukuran $29 \mathrm{~cm}$ x $29 \mathrm{~cm}$ x $30 \mathrm{~cm}$ yang diisi $17 \mathrm{~L}$ air dan diberi aerasi. Pemijahan menggunakan perbandingan induk jantan : betina $=1: 3$ yaitu 10 ekor jantan yang dipasangkan dengan 40 ekor betina. Selama pemijahan induk diberi pakan seperti saat proses adaptasi.

Pemijahan menggunakan tali rafia berwarna hitam sebagai substrat penempelan telur. Tali rafia tersebut dipotong sepanjang $8 \mathrm{~cm}$ dan dihaluskan menyerupai akar tanaman air. Perbandingan jumlah substrat dengan jumlah betina adalah $4: 1$. Substrat untuk pemijahan diikat menjadi satu kelompok dan diletakkan di permukaan air pada salah satu sudut wadah pemijahan. Substrat dimasukkan ke dalam wadah pada pagi hari karena aktivitas pemijahan ikan I. Werneri lebih serempak pada pagi hari (Herjayanto, 2016) sehingga memudahkan koleksi telur untuk pengamatan.

\section{Pengamatan embriogenesis}

Embrio yang digunakan untuk pengamatan sebanyak 400 butir yang diperoleh dari pemijahan secara massal dengan cara menaruh substrat selama 5 menit dalam wadah pemijahan. Substrat yang telah terdapat telur dipindahkan masing-masing 100 butir ke dalam empat buah wadah inkubasi masingmasing berukuran $(19,5 \times 13,5 \times 8,5) \mathrm{cm}^{3}$ yang diisi air setinggi $3 \mathrm{~cm}$.

Fase perkembangan embrio diamati di bawah mikroskop dengan cara mengambil embrio menggunakan pinset lalu diletakkan pada kaca preparat cekung. Waktu dan gambar setiap tahap perkembangan embrio dicatat dan didokumentasikan, terutama pada fase tertentu seperti pembelahan sel, morula, blastula, gastrula, organogenesis dan penetasan.

\section{Pengamatan perkembangan larva dan viabilitas reproduksi}

Pengamatan parameter perkembangan larva dan viabilitas reproduksi menggunakan 1.000 butir embrio. Embrio diperoleh dengan cara meletakkan substrat pada pagi hari (pukul 06.00) dalam wadah pemijahan dan kemudian dihitung jumlahnya pada sore hari (pukul 17.30). Masing-masing 200 butir embrio dimasukkan ke dalam lima buah wadah berukuran $(19,5 \times 19,5 \times 19,5) \mathrm{cm}^{3}$. Wadah tersebut diisi air setinggi $3 \mathrm{~cm}$ dan perlahan dinaikkan volumenya seiring dengan waktu pemeliharaan ikan. Masing-masing wadah diberi aerasi untuk menyuplai oksigen terlarut. Pada bagian atas wadah pemeliharaan ditambahkan lampu TL 40 watt dengan jarak $60 \mathrm{~cm}$ dari wadah sebagai sumber cahaya untuk mendukung sifat larva yang vision feeding.

Pengamatan perkembangan larva dilakukan secara makroskopis dengan mengamati ciri morfologi, tingkah laku larva, pertumbuhan panjang total pada hari ke- $0,14,28$ dan 50 setelah menetas serta jenis pakan yang diberikan selama pemeliharaan. Kemudian parameter viabilitas reproduksi yang diamati adalah lama masa inkubasi telur, tingkat penetasan telur, tingkat kelangsungan hidup dan persentase ikan jantan. Parameter lama masa inkubasi telur diamati dengan cara menghitung jumlah larva yang menetas tiap hari. Tingkat penetasan telur diamati pada hari ketujuh yaitu saat semua embrio telah menetas. Kemudian tingkat kelangsungan hidup diamati pada hari ke-14, 28 dan 50 setelah semua larva menetas. Pengamatan persentase kelamin jantan dilakukan pada hari ke-50 melalui pengamatan gonad ikan secara histologi menggunakan pewarnaan asetokarmin berdasarkan metode Nurkhasanah (2015).

\section{Prosedur analisis data}

Data embriogenesis, perkembangan larva dan viabilitas reproduksi yang diperoleh dianalisis secara deskriptif dan disajikan dalam bentuk gambar dan tabel.

\section{Hasil Dan Pembahasan}

\section{Embriogenesis}

Embriogenesis atau perkembangan embrio yaitu keseluruhan proses yang meliputi proses perkembangan setelah fertilisasi (pembuahan) sampai dengan organogenesis sebelum ikan menetas (Rahardjo dkk., 2011). Hasil pengamatan menunjukkan bahwa telur ikan pelangi I. Werneri termasuk telolecithal, berwarna bening sampai bening keemasan. Pada bagian kutub anima terdapat filamenfilamen yang berwarna agak keemasan yang akan menempel pada substrat. Diameter telur I. werneri dibandingkan spesies ikan pelangi lain dapat dilihat pada Tabel 1 . 
Muh. Herjayanto : Embriogenesis, Perkembangan Larva dan Viabilitas Reproduksi Ikan Pelangi Iriatherina Werneri Meinken, 1974 Pada Kondisi Laboratorium

Tabel 1. Diameter telur ikan pelangi Iriatherina werneri dibandingkan spesies ikan pelangi yang lain. Table 1. Diameter rainbow fish Iriatherina werneri eggs than other species of rainbow fish.

\begin{tabular}{lcccccl}
\hline Spesies & $\begin{array}{c}\text { Diameter } \\
(\mathrm{mm})\end{array}$ & $\begin{array}{c}\sum \mathrm{BM} \\
(\mathrm{buah})\end{array}$ & $\begin{array}{c}\mathrm{DBM} \\
(\mathrm{mm})\end{array}$ & $\begin{array}{c}\sum \mathrm{F} \\
(\mathrm{helai})\end{array}$ & $\begin{array}{c}\mathrm{PF} \\
(\mathrm{mm})\end{array}$ & Sumber \\
\hline Iriatherina werneri & $0,73-1,08$ & $\mathrm{Td}$ & $\mathrm{Td}$ & $\mathrm{td}$ & $\mathrm{td}$ & (Herjayanto, 2016) \\
Melanotaenia nigrans & $1,00-1,08$ & $45-55$ & $0,02-0,07$ & $\mathrm{td}$ & $20-30$ & (Crowley \& Ivantsoff, 1982) \\
M. splendida inornata & $0,87-0,92$ & $55-65$ & $0,01-0,08$ & $\mathrm{td}$ & $20-30$ & (Crowley \& Ivantsoff, 1982) \\
M. splendida splendida & $0,93-1,20$ & $35-60$ & $0,01-0,12$ & $30-40$ & $3-8$ & (Humphrey et al., 2003) \\
M. arfakensis & $0,50-1,30$ & $\mathrm{Td}$ & $\mathrm{Td}$ & $\mathrm{td}$ & $\mathrm{td}$ & (Manangkali $d k k ., 2009)$ \\
Glossolepis incisus & $0,95-1,05$ & $\mathrm{Td}$ & $\mathrm{Td}$ & $27-29$ & $\mathrm{td}$ & (Nugraha, 2004) \\
\hline
\end{tabular}

Keterangan: jumlah butiran minyak $\left(\sum \mathrm{BM}\right)$, diameter butiran minyak $(\mathrm{DBM})$, jumlah filamen $\left(\sum \mathrm{F}\right)$, panjang filamen $(\mathrm{PF})$, tidak ada data (td)

Embrio akan mengalami berbagai perkembangan hingga menetas. Perkembangan tersebut dapat dibagi menjadi lima fase yaitu pembelahan sel (cleavage), kemudian morula, blastula, gastrula dan organogenesis (Tabel 2 dan Gambar 2).

Tabel 2. Embriogenesis ikan pelangi Iriatherina werneri pada suhu inkubasi $24-30{ }^{\circ} \mathrm{C}$.

Table 2. Rainbow fish Iriatherina werneri embryogenesis at an incubation temperature of $24-30^{\circ} \mathrm{C}$.

\begin{tabular}{|c|c|c|}
\hline $\begin{array}{l}\text { Umur (setelah } \\
\text { pembuahan) }\end{array}$ & Fase & Deskripsi secara mikroskopis \\
\hline 0 menit & $\begin{array}{l}\text { Belum } \\
\text { membelah }\end{array}$ & $\begin{array}{l}\text { Butiran minyak (oil droplets) menyebar terutama pada kutub } \\
\text { anima }\end{array}$ \\
\hline 51 menit & $\begin{array}{l}\text { Belum } \\
\text { membelah }\end{array}$ & $\begin{array}{l}\text { Satu sel terlihat pada kutub anima, butiran minyak perlahan } \\
\text { bergerak ke arah kutub vegetal }\end{array}$ \\
\hline 53 menit & Pembelahan sel & Sel mulai membelah menjadi dua sel \\
\hline 1 jam 22 menit & Pembelahan sel & Ukuran sel telah maksimal dan akan melakukan pembelahan \\
\hline 1 jam 33 menit & Pembelahan sel & Terlihat empat sel, namun ukuran selnya belum maksimal \\
\hline 3 jam 14 menit & Morula & $\begin{array}{l}\text { Ukuran sel semakin kecil dan jumlah semakin banyak (>32 sel), } \\
\text { butiran minyak telah berkumpul pada kutub vegetal }\end{array}$ \\
\hline 5 jam 55 menit & Blastula & Fase awal blastula, blastodisk menyerupai gundukan \\
\hline 11 jam 48 menit & Gastrula & $\begin{array}{l}\text { Fase awal gastrula, blastoderm mulai menutupi setengah bagian } \\
\text { kuning telur dan terus bergerak ke arah kutub vegetal }\end{array}$ \\
\hline 15 jam 07 menit & Gastrula & $\begin{array}{l}\text { Fase akhir gastrula, blastoderm menutupi hampir seluruh kuning } \\
\text { telur dan cincin kecambah semakin menebal }\end{array}$ \\
\hline 28 jam 19 menit & Organogenesis & $\begin{array}{l}\text { Kepala dan ekor telah dapat dibedakan, rongga mata mulai } \\
\text { terbentuk dan kemudian diikuti oleh pembentukan somit }\end{array}$ \\
\hline 33 jam 20 menit & Organogenesis & Mata semakin membulat, jantung dan pembuluh darah belum ada \\
\hline 52 jam 15 menit & Organogenesis & $\begin{array}{l}\text { Mata belum berpigmen, ukuran tubuh semakin besar, jantung dan } \\
\text { aliran darah sudah ada }\end{array}$ \\
\hline 55 jam 03 menit & Organogenesis & $\begin{array}{l}\text { Mata semakin menebal dan terlihat titik-titik pigmen hitam pada } \\
\text { bagian pinggir mata }\end{array}$ \\
\hline 57 jam 26 menit & Organogenesis & $\begin{array}{l}\text { Pigmen mata dan tubuh bertambah banyak, embrio ikan telah } \\
\text { bergerak }\end{array}$ \\
\hline 76 jam 13 menit & Organogenesis & $\begin{array}{l}\text { Mata telah sepenuhnya hitam, sirip dada telah ada dan gerakan } \\
\text { embrio semakin aktif }\end{array}$ \\
\hline 86 jam 53 menit & Organogenesis & $\begin{array}{l}\text { Bentuk badan semakin memanjang, ekor semakin meruncing dan } \\
\text { gerakan semakin aktif }\end{array}$ \\
\hline 124 jam 05 menit & Menetas & Larva \\
\hline
\end{tabular}




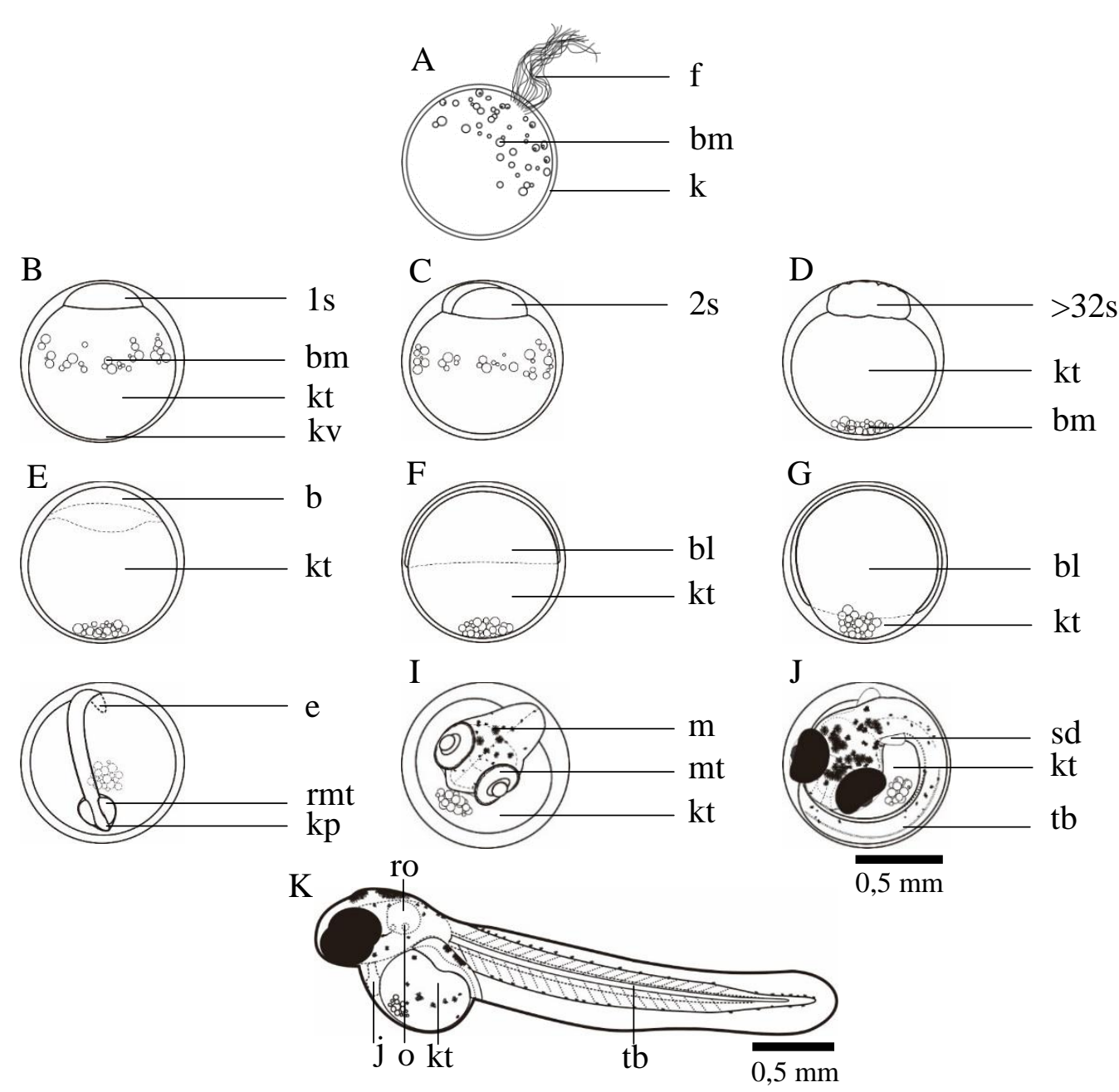

Gambar 2 Embriogenesis Iriatherina werneri pada suhu inkubasi $24-30{ }^{\circ} \mathrm{C}$. Fase perkembangan berdasarkan waktu: (A) 0 menit; (B) 51 menit; (C) 1 jam 22 menit; (D) 3 jam 14 menit; (E) 5 jam 55 menit; (F) 11 jam 48 menit; (G) 15 jam 07 menit; (H) 28 jam 19 menit; (I) 55 jam 03 menit; (J) 76 jam 13 menit; (K) 124 jam 05 menit. 1s: 1 sel; 2s: dua sel; >32s: lebih dari 32 sel; b: blastodisk; bl: blastoderm; bm: butiran minyak; e: ekor; f: filamen; j: jantung; k: korion; kp: kepala; kt: kuning telur; kv: kutub vegetal; m: melanofor; mt: mata; o: otolith; rmt: rongga mata; ro: rongga otic (otic vesicle); sd: sirip dada; tb: tulang belakang.

Figure 2 Embryogenesis at Iriatherina werneri in incubation temperature of $24-30^{\circ} \mathrm{C}$. Phase of development by time: (A) 0 min; (B) 51 minutes; (C) 1 hour 22 minutes; (D) 3 hours 14 minutes; (E) 5 hours 55 minutes; (F) 11 hours 48 minutes; (G) 15 hours 07 minutes; (H) 28 hours 19 minutes; (I) 55 hours 03 minutes; (J) 76 hours 13 minutes; (K) 124 hours 05 minutes. 1s: 1 cells; $2 \mathrm{~s}$ : two cells; > 32s: more than 32 cells; b: blastodisk; bl: blastoderm; bm: oil droplets; e: tail; f: filament; j: heart; k: chorion; kp: head; kt: egg yolk; kv: vegetal pole; m: melanofor; mt: eye; o: otolith; rmt: eye socket; ro: otic cavity (otic vesicles); sd: pectoral fin; tb: spine.

Gambar 2.A-2.D menunjukkan bahwa selama fase pembelahan sel, butiran minyak (oil droplets) terus bergerak ke arah kutub vegetal. Selama fase ini, sel melakukan mitosis terus menerus secara cepat sehingga menjadi sel-sel berukuran lebih kecil yang disebut blastomer (Rahardjo dkk., 2011). Perkembangan embrio setiap spesies ikan berbeda-beda, selain itu proses tersebut bergantung pada suhu media inkubasinya, semakin tinggi suhu maka proses penetasan semakin cepat.

Beberapa penelitian telah melaporkan embriogenesis pada ikan pelangi misalnya 
Muh. Herjayanto : Embriogenesis, Perkembangan Larva dan Viabilitas Reproduksi Ikan Pelangi Iriatherina Werneri Meinken, 1974 Pada Kondisi Laboratorium

pada spesies Melanotaenia nigrans, pembelahan pertama terjadi saat embrio berumur 1 jam 30 menit dan menetas saat umur embrio 155-159 jam, kemudian pada spesies $M$. splendida inornata pembelahan pertama terjadi saat 1 jam 15 menit dan menetas setelah 151-152 jam pada suhu $25 \pm 1$ ${ }^{\circ} \mathrm{C}$ (Crawley \& Ivantsoff, 1982), kemudian pada embrio M. splendida splendida pembelahan pertama terjadi pada umur embrio 1 jam dan menetas setelah 105 jam atau setelah empat hari pada suhu $28 \pm 1{ }^{\circ} \mathrm{C}$ (Humphrey et al., 2003). Pada ikan pelangi merah Glossolepis incisus terjadi saat embrio berumur 1 jam 13 menit dan menetas setelah 168 jam atau tujuh hari setelah pembuahan pada suhu inkubasi $27-28{ }^{\circ} \mathrm{C}$ (Nugraha, 2004) dan pada Melatonia spp. asal sungai Gelap Papua embrio menetas setelah 127 jam 4 menit atau lima hari setelah pembuahan pada suhu 25,8-26,0 ${ }^{\circ} \mathrm{C}$ (Chumaidi $d k k$., 2009).

Saat fase organogenesis, perkembangan yang sangat terlihat adalah perkembangan mata, perkembangan tubuh dan pigmen melanofor. Pada fase organogenesis, embrio bintik mata terjadi saat embrio berumur antara 55 jam sampai 124 jam (sebelum embrio menetas). Perkembangan selama embriogenesis menggunakan energi yang berasal dari kuning telur, hal ini terlihat dari ukuran kuning telur yang semakin kecil. Menurut Budiardi dkk., (2005) bahwa penyerapan kuning telur selama embriogenesis dipengaruhi oleh suhu. Pada suhu yang optimum, dapat diperoleh efisiensi pemanfaatan kuning telur untuk pembentukan jaringan tubuh.

\section{Perkembangan Larva}

Embrio yang menetas disebut larva. Setelah menetas, larva kemudian mengalami perkembangan hingga menyerupai individu dewasa (juvenil) (Tabel 3). Perkembangan tersebut meliputi transformasi sistem organ dan bentuk tubuh (Rahardjo dkk., 2011).

Tabel 3. Perkembangan morfologi ikan pelangi Iriatherina werneri

Table 3. Morphology development of rainbow fish Iriatherina werneri

\begin{tabular}{ccl}
\hline $\begin{array}{c}\text { Umur (hari } \\
\text { setelah } \\
\text { menetas) }\end{array}$ & $\begin{array}{c}\text { Panjang } \\
\text { total }(\mathrm{mm})\end{array}$ & Deskripsi secara makroskopis \\
\hline 0 & $3,36-3,68$ & $\begin{array}{l}\text { Tubuh transparan dan masih memiliki kuning telur. Sirip ekor } \\
\text { masih menyatu bersama sirip punggung dan sirip anal }\end{array}$ \\
14 & $6,77-8,48$ & $\begin{array}{l}\text { Sirip punggung dan anal mulai terlihat jelas, pinggiran sirip } \\
\text { berwarna hitam dan sirip ekor kekuningan }\end{array}$ \\
28 & $11,06-$ & $\begin{array}{l}\text { Sirip ekor telah bercagak dan warnanya seperti ikan dewasa, sirip } \\
\text { punggung dan anal berwarna kekuningan }\end{array}$ \\
50 & 12,00 & Perkembangan sirip dan tubuh telah sempurna \\
$19,64-$ & 21,56 & \\
\hline
\end{tabular}

Larva ikan pelangi I. werneri yang baru menetas terlihat berenang secara vertikal ke permukaan air, kemudian jatuh ke dasar wadah, sesaat larva terlihat diam di dasar wadah dan kembali berenang secara vertikal ke permukaan air. Gerakan ini diindikasikan sebagai gerakan jarky motion yaitu gerakan dalam upaya untuk mengisi gelembung renang dengan udara (Mulyani, 2015). Gelembung renang yang telah terisi berfungsi sebagai organ yang membantu pergerakan larva terutama untuk berenang mencari makan.

Jenis pakan yang diberikan selama pemeliharaan $I$. werneri adalah Infusoria, Rotifera, nauplii Artemia sp., Moina sp. dan pakan buatan berbentuk tepung (Tabel 4). Jenis pakan lain yang juga dapat diberikan adalah Tubifex, Chironomus dan Daphnia (Said dkk., 2006). Hasil pengamatan menunjukkan larva umur 1 hari setelah menetas (hsm) telah dapat memakan Infusoria atau Rotifera. Hal ini diketahui melalui gerakan larva yang membengkokkan tubuhnya kemudian berenang maju secara tiba-tiba. Gerakan ini merupakan gerakan larva makan secara predatory snapping. Hal ini menandakan bahwa mulut larva $I$. werneri telah terbuka saat berumur 1 hsm. Dilaporkan pada ikan pelangi $M$. splendida splendida, mulut telah terbentuk sepenuhnya sejak embrio belum menetas yaitu 
pada fase organogenesis (umur 96 jam setelah pembuahan) (Humphrey et al., 2003). Pemberian pakan yang lebih awal dianjurkan untuk mendukung perkembangan larva, sehingga terdapat dua sumber energi yaitu dari kuning telur (endogenous) dan dari pakan alami (exsogenous).

Tabel 4. Jenis pakan berdasarkan umur ikan pelangi Iriatherina werneri

Table 4.Type of feed based on the age of the rainbow fish Iriatherina werneri

\begin{tabular}{ccc}
\hline Umur (hari setelah menetas) & Jenis pakan & Sistem pemberian pakan \\
\hline $1-21$ & Infusoria dan Rotifera & Selalu tersedia (ad libitum) \\
$8-30$ & Nauplii Artemia sp. & At satiation $(07.00,12.00,18.00)$ \\
$30-50$ & Moina sp. dan pakan buatan & At satiation $(07.00,12.00,18.00)$ \\
\hline
\end{tabular}

Larva ikan I. werneri telah dapat berenang secara horizontal pada umur $1 \mathrm{hsm}$. Kuning telur mulai habis pada umur $3 \mathrm{hsm}$. Beberapa larva saat berumur $8 \mathrm{hsm}$ telah dapat memakan nauplii Artemia dan pada umur $30 \mathrm{hsm}$ telah dapat memakan Moina sp. Secara keseluruhan umur $>35$ hsm larva telah menjadi juvenil dan dapat diberikan pakan buatan berbentuk tepung. Pada ikan pelangi merah G. incisus, larva mencapai bentuk definitif pada umur 38 hsm (Nugraha, 2004). Kemudian pada spesies M. splendida splendida, sirip telah terbentuk sempurna setelah $>25 \mathrm{hsm}$ (panjang standar 12,2-13,6 mm) dan sekitar umur 90 hsm ikan telah mencapai matang kelamin (Humphrey et al., 2003).

\section{Viabilitas Reproduksi}

Pengamatan viabilitas reproduksi untuk mengetahui kemampuan reproduksi ikan melalui pengamatan beberapa parameter reproduksi (Said, 2008). Hasil pengamatan terhadap lama masa inkubasi telur menunjukkan bahwa embrio ikan pelangi $I$. werneri tidak menetas $100 \%$ pada hari yang sama. Penetasan berlangsung selama tiga hari, sehingga lama inkubasi embrio sampai menetas seluruhnya adalah enam hari. Embrio mulai menetas pada hari keempat setelah pembuahan dan berakhir pada hari keenam setelah pembuahan. Puncak jumlah embrio yang menetas terjadi pada hari kelima setelah pembuahan (Gambar 3). Humphrey et al. (2003) melaporkan bahwa embrio $M$. splendida splendida membutuhkan waktu inkubasi sampai delapan hari setelah pembuahan, telur menetas pada hari keempat dan puncak penetasan terjadi pada hari kelima.

Hasil pengamatan terhadap tingkat penetasan telur, tingkat kelangsungan hidup dan persentase ikan jantan dapat dilihat pada Tabel 5.

Pada penelitian ini diperoleh tingkat penetasan telur terendah $41,50 \%$ dan tertinggi sebesar 87,20\%. Selanjutnya dengan menggunakan sistem pemberian pakan seperti tertera pada Tabel 4, diperoleh tingkat kelangsungan hidup pada akhir penelitian berkisar 23,91-91,57\%. Viabilitas reproduksi tersebut masih berada pada kisaran yang baik jika dibandingkan hasil penelitian lain pada ikan yang sama (Tabel 6). Selain kesesuaian jenis pakan yang diberikan, faktor lain yang mempengaruhi tingkat kelangsungan hidup ikan adalah induk yang digunakan, kualitas telur, kualitas air dan cara penanganan ikan selama pemeliharaan. 
Muh. Herjayanto : Embriogenesis, Perkembangan Larva dan Viabilitas Reproduksi Ikan Pelangi Iriatherina Werneri Meinken, 1974 Pada Kondisi Laboratorium

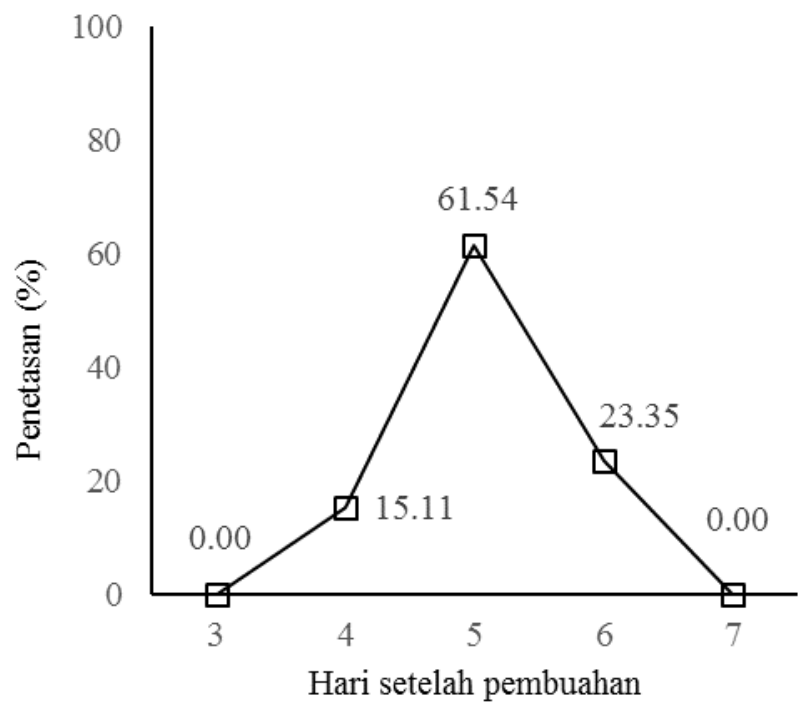

Gambar 3. Hasil kurva penetasan embrio Iriatherina werneri setelah hari pembuahan pada suhu inkubasi $24-30{ }^{\circ} \mathrm{C}$.

Figure 3. Results Iriatherina werneri curve hatching embryo after fertilization day at an incubation temperature of $24-30{ }^{\circ} \mathrm{C}$.

Tabel 5. Viabilitas reproduksi pada ikan Iriatherina werneri

Table 5 . Viability of reproduction in Iriatherina werneri fish

\begin{tabular}{cccccc}
\hline Nomor wadah & TPt $(\%)$ & TKH14 $(\%)$ & TKH28 $(\%)$ & TKH50 $(\%)$ & $\hat{\delta}(\%)$ \\
\hline 1 & 41,50 & 100,00 & 92,77 & 91,57 & 20,00 \\
2 & 50,50 & 69,09 & 61,82 & 59,09 & 8,00 \\
3 & 58,00 & 64,66 & 50,00 & 50,00 & 12,00 \\
4 & 87,20 & 38,04 & 23,91 & 23,91 & 20,00 \\
5 & 73,20 & 92,42 & 89,04 & 89,04 & 40,00 \\
\hline Rata-rata & $62,04 \pm 18,20$ & $72,85 \pm 24,57$ & $64,63 \pm 28,61$ & $62,72 \pm 28,31$ & $20,00 \pm 12,33$
\end{tabular}

Keterangan: Tingkat penetasan telur (TPt), tingkat kelangsungan hidup pada hari ke-14, 28 dan 50 (TKH14, TKH28 dan TKH50) dan ikan jantan (ठ̊)

Tabel 6. Beberapa hasil penelitian viabilitas reproduksi pada ikan Iriatherina werneri

Table 6. Some research the viability of reproduction in Iriatherina werneri fish.

\begin{tabular}{cccccc}
\hline Sumber & TPt $(\%)$ & TKH50 $(\%)$ & TKH60 (\%) & TKH70 (\%) & \multirow{\sigma}{1}{$(\%)$} \\
\hline Nurkhasanah (2015) & 79,33 & 24,00 & - & - & 10,00 \\
Rakhmawati (2016) & 43,40 & - & 40,30 & - & 30,00 \\
Firmansyah (2016) & $75,50-77,33$ & - & - & $37,44-52,55$ & $22,27-24,49$
\end{tabular}

Keterangan: Tingkat penetasan telur (TPt), tingkat kelangsungan hidup pada hari ke-50, 60 dan 70 (TKH50, TKH60 dan TKH70) dan ikan jantan (ð)

Jumlah ikan jantan I. werneri yang sangat sedikit termasuk salah satu masalah dalam budidaya ikan ini. Hal ini disebabkan karena hanya ikan I. werneri jantan yang digemari di pasar ikan hias. Beberapa penelitian telah dilakukan untuk meningkatkan jumlah populasi jantan $I$. werneri yaitu melalui penggunaan ekstrak tanaman purwoceng (Nurkhasanah, 2015) dan peningkatan suhu pemeliharaan (Rakhmawati, 2016) dengan 
hasil tertinggi yaitu $67 \%$ dan $73,33 \%$ jantan, namun masih perlu perbaikan pada tingkat kelangsungan hidup yang diperoleh pada akhir pemeliharaan. Kemudian peningkatan jantan melalui penelitian produksi jantan super yang dilakukan oleh Firmansyah (2016) masih membutuhkan penelitian lanjutan untuk produksinya secara massal.

\section{Kesimpulan}

Proses embriogenesis ikan pelangi I. werneri membutuhkan waktu yang lama sampai menetas yaitu empat sampai enam hari setelah pembuahan. Ikan telah menjadi juvenil pada umur 35 hari setelah menetas dengan panjang total $>12 \mathrm{~mm}$. Pada penelitian ini diperoleh rata-rata tingkat penetasan telur sebesar $62,04 \%$, tingkat kelangsungan hidup umur 50 hari setelah menetas $62,72 \%$ dan jumlah ikan jantan $20 \%$.

\section{Daftar Pustaka}

Allen GR 1980. A generic classification of the rainbowfishes (family Melanotaeniidae). Records of the Western Australia Museum, 8(3): 449-490.

Budiardi T, Cahyaningrum W, Effendi I. 2005. Efisiensi pemanfaatan kuning telur embrio dan larva ikan maanvis Pterophyllum scalare pada suhu inkubasi yang berbeda. Jurnal Akuakultur Indonesia. 4(1): 57-61.

Chumaidi, Nur B, Sudarto, Pouyaud L, Slembrouck J. 2009. Pemijahan dan perkembangan embrio ikan pelangi, Melanotaeenia spp. asal Papua. Jurnal Perikanan. 11(2): 131-137.

Çelik İ, Çelik P, Cirik Ş, Gürkan M, Hayretdağ S. 2011. Embryonic and larval development of black skirt tetra Gymnocorymbus ternetzi Boulenger, 1895 under laboratory conditions. Aquaculture Research. 1-16.

Crowley LELM, Ivanstsoff W. 1982. Reproduction and early stages of development in two species of Australian rainbowfishes, Melanotaenia nigrans Richardson and Melanotaenia splendida inornata
Castelnau. Australia Zoology. 21(1): 85-95.

Firmansyah R. 2016. Feminisasi ikan rainbow Iriatherina werneri dengan hormon estradiol-17 $\beta$. [tesis]. IPB, Bogor.

Herjayanto M. 2016. Kajian tingkah laku memijah, potensi reproduksi ikan betina dan optimasi teknik pemijahan ikan pelangi Iriatherina werneri. [tesis]. IPB, Bogor.

Humphrey C, Klumpp DW, Pearson R. 2003. Early development and growth of the eastern rainbowfish Melanotaenia splendida splendida (Peters) I. Morphogenesis and ontogeny. Marine and Freshwater Research. 54: 17-25.

Manangkali E, Rahardjo MF, Sjafei DS, Sulistiono. 2009. Musim pemijahan ikan pelangi Arfak Melanotaenia arfakensis (Allen) di sungai Nimbai dan sungai Aimasi, Manokwari. Jurnal Ikhtiologi Indonesia. 9(1): 112.

Mulyani YWT. 2015. Efisiensi penyerapan kuning telur dan morfogenesis pralarva ikan arwana silver Osteoglossum bicirrhosum Cuvier, 1829 pada suhu dan salinitas berbeda. [tesis]. IPB, Bogor.

Nugraha F. 2004. Embriogenesis dan perkembangan larva ikan rainbow Glossolepis incisus. [skripsi]. IPB, Bogor.

Nurkhasanah A. 2015. Maskulinisasi ikan pelangi Iriatherina werneri melalui perendaman embrio dalam ekstrak tanaman purwoceng Pimpinella alpina. [skripsi]. IPB, Bogor.

Rahardjo MF, Sjafei DS, Affandi R, Sulistiono. 2011. Iktiologi. Lubuk Agung, Bandung. 394 p.

Rahmadani. 2015. Performa pemijahan ikan pelangi Iriatherina werneri dengan perbedaan lama waktu pengistirahatan induk. [skripsi]. IPB, Bogor.

Rakhmawati WN. 2016. Nisbah kelamin ikan pelangi Iriatherina werneri pada 
Muh. Herjayanto : Embriogenesis, Perkembangan Larva dan Viabilitas Reproduksi Ikan Pelangi Iriatherina Werneri Meinken, 1974 Pada Kondisi Laboratorium

perbedaan suhu pemeliharaan. [skripsi]. IPB, Bogor.

Said DS, Triyanto, Fauzi, Hasan. 2006. Adaptasi jenis pakan untuk pertumbuhan ikan pelangi irian Iriatherina werneri. Limnotek. 13(2): 53-59.

Said DS. 2008. Viabilitas reproduksi dan pertumbuhan ikan pelangi mungil Melanotaenia praecox pada habitat terkontrol. Limnotek. 15(1): 31-39.

Tappin AR. 2011. Rainbowfishes their care and keeping in captivity. 2nd edition. Art Publications, Queensland. 557 p.
Trappett A, Condon CH, White C, Matthews P, Wilson RS. 2013. Extravagant ornaments of male threadfin rainbowfish Iriatherina werneri are not costly for swimming. Functional Ecology, 1-8.

Unmack PJ, Allen GR, Johnson JB. 2013. Phylogeny and biogeography of rainbowfishes (Melanotaeniidae) from Australia and New Guinea. Molecular Phylogenetics and Evolution, 67: 15-27. 